\title{
RESEARCH
}

Open Access

\section{The association between toll-like receptor 4 (TLR4) genotyping and the risk of epilepsy in children}

\author{
Maha Abdelsalam ${ }^{1,2^{*}}$ (D), Dina Salama Abd Elmagid ${ }^{3}$, Hend Magdy ${ }^{4}$, Amr Mohamed El-Sabbagh ${ }^{5}$ and
} Maged Mostafa'

\begin{abstract}
Background: Epilepsy is one of the most widely recognized neurological disorders; unfortunately, twenty to thirty percent of patients do not get cured from epilepsy, despite many trials of antiepileptic drug (AED) therapy. Immunotherapy may be a viable treatment strategy in a subset of epileptic patients. The association between Tolllike receptor polymorphisms and epilepsy clarifies the role of the immune system in epilepsy and its response to the drug. Thus, this study will focus on the relation between TLR4 rs1927914, rs11536858, rs1927911SNPs, and epilepsy in an Egyptian case-control study to assess their link to antiepileptic drug response.

Results: According to TLR4 rs 1927914, there is a significant association between the SNP and the development of epilepsy, as CC genotype is 15.3 times more at risk for developing epilepsy than $\Pi$ genotype, and CT is 11.1 times more at risk for developing epilepsy than $\Pi$. Also, patients with CC genotypes are 6.3 times more at risk for developing primary epilepsy than $\Pi$ genotype.

According to rs11536858, there is a significant association between cases and control groups, as AA genotypes are found to be more at risk for developing epilepsy than GG genotypes. Also, there is a statistically significant association between clonazepam resistance and rs11536858, as $p$ value $<0.001^{*}$ with the highest frequency of $\Pi T$ genotypes at $4.3 \%$.

According to rs1927911, there are no significant results between the cases and the control groups or between drug-responsive and drug resistance.

Conclusion: Possible involvement of the Toll-like receptor clarifies the importance of innate immunity in initiating seizures and making neuronal hyperexcitability. In this work, multiple significant associations between TLR SNPs and epilepsy, epileptic phenotype, and drug-resistant epilepsy have been found. More studies with bigger sample sizes and different techniques with different SNPs are recommended to find the proper immunotherapy for epilepsy instead of the treatment by antiepileptic drugs.
\end{abstract}

Keywords: Antiepileptic drug-resistant, Egyptian, Innate immunity, PCR, Pediatric, RFLP

\footnotetext{
*Correspondence: dr_mahy20062006@yahoo.com

1 Immunology Unit, Clinical Pathology Department, Faculty of Medicine,

Mansura University, Mansoura, Egypt

${ }^{2}$ Immunology Department, Egypt Center for Research and Regenerative

Medicine (ECRRM), Cairo 11517, Egypt

Full list of author information is available at the end of the article
}

\section{Springer Open}

(c) The Author(s). 2020 Open Access This article is licensed under a Creative Commons Attribution 4.0 International License, which permits use, sharing, adaptation, distribution and reproduction in any medium or format, as long as you give appropriate credit to the original author(s) and the source, provide a link to the Creative Commons licence, and indicate if changes were made. The images or other third party material in this article are included in the article's Creative Commons licence, unless indicated otherwise in a credit line to the material. If material is not included in the article's Creative Commons licence and your intended use is not permitted by statutory regulation or exceeds the permitted use, you will need to obtain permission directly from the copyright holder. To view a copy of this licence, visit http://creativecommons.org/licenses/by/4.0/. 


\section{Background}

Epilepsy is one of the most widely recognized neurological disorders, and seizures are its main symptom with emotional and cognitive dysfunction, which affects $\approx 50$ million people worldwide. Many experimental and clinical research studies showed the active role of the two arms of the immune system (innate and adaptive) in the pathogenesis of epilepsy via inflammation. Also, inflammatory cytokines and immune cells were reported to have a significant role in the initiation and relapse of epileptic seizures and the association of other diseases with epilepsy [1]. In the brain, TLR4 is expressed by astrocytes and microglia; the presence of TLR on glial cells and their limited expression on neurons have been evidenced by various studies. The expression of TLR mRNA on human microglial cells has been demonstrated with high cell surface and intracellular expression of TLR2 and TLR3, respectively [1].

The capacity of ligand binding with TLR4 may be changed due to alteration in the signals caused by single-nucleotide polymorphisms (SNPs) in the extracellular domain of TLR4 which will then alter the level of cytokines either pro- or anti-inflammatory cytokines and hence alter the susceptibility of chronic inflammation. Three SNPs of TLR4 gene, namely, rs11536858 (now merged into rs10759931), rs1927911, and rs1927914, are reported to be associated with inflammatory diseases [2]. The regions of rs1927911 (7764C $>\mathrm{T})$, rs1927914 (2437T $>C)$, and rs10759931 (2688A $>$ G) are Intron 1, 5'UTR, and promoter respectively; their locations are Chromosome 9:117707776, Chromosome 9:117702447, and Chromosome 9:117701869 respectively, and their minor allele frequencies (MAF) are $0.40,0.49$, and 0.35 respectively. All data were collected from the Ensemble Genome Browser (www.ensembl.org). These SNPs rs1927911, rs1927914, and rs10759931 have not been previously studied in Egypt.

An experimental study on murine microglia using real-time PCR has shown an expression of TLRs 1-9 and a condensed expression of TLRs 2, 4, 6, 8, and 9 mRNA in response to IFN-g, as well as a reaction to lipopolysaccharide (LPS). During pathogen recognition, TLR4 receptors interacted with intracellular protein MyD88 after the stimulation of the IL-1b/IL-1b R axis.
HMGB1 is one of the damage-associated molecular patterns (DAMPs) that is passively released from necrotic cells and actively secreted by cells that are exposed to significant stress, which are recognized by TLR-signaling pathways. Also, an increase in the expression of TLR4 and HMGB1 in neurons has been observed in chemical epilepsy models [3].

HMGB1-TLR4 signaling has a significant role in the pathogenesis of epilepsy, which was confirmed by studies that were performed on human hippocampal tissue from intractable temporal lobe epilepsy patients, but with unknown source of HMGB1 secretion, or the cause of initiation of this pathway. Also, seizure frequency and duration had been limited by trials using HMGB1-TLR4 antagonists. Those antagonists have been studied on the bicuculline-induced non-lesional model of seizures, leading to an increase in the onset of the latency period [3].

Suleiman et al. documented many epileptic cases with severe resistance to antiepileptic drugs (AED), but at the same time, they responded to immune therapy; these cases confirm the link between immune dysregulation and epilepsy, especially drug-resistant epilepsy [4]. Thus, a strong study should be constructed to highlight the relation between immune dysregulation, epilepsy, and the epileptic drug. Antiepileptic drugs (AEDs) are commonly available, but unfortunately, they have a risk of idiosyncratic effects, such as allergic reactions and organ damage. Also, about one third of epileptic patients have AEDs resistance; thus, an urgent need exists for effective therapies to be developed [5].

Therefore, in our current study, we aimed to determine the relation between TLR4 rs1927914, rs11536858, rs1927911, and epilepsy in an Egyptian case-control study and to study their relation to clinical data and response to antiepileptic drug (AED) therapy.

\section{Methods \\ Patients}

The study involved 133 Egyptian children divided into two groups: group I (83 pediatric patients), who were recruited to the inpatient and outpatient clinic of the pediatric neurology unit of a children hospital in 20172018 (40 boys and 43 girls), and group II. Group I has

Table 1 Primers for PCR-RFLP of the TLR4, restriction enzymes used, and RFLP products size and genotypes

\begin{tabular}{|c|c|c|c|c|}
\hline SNP ID & Prime & Sequence & Restriction enzyme used & RFLP product size and genotypes \\
\hline \multirow[t]{2}{*}{ rs11536858 } & Forward & ATAACCTCAGTGGGCTCTGG & \multirow[t]{2}{*}{ Kpnl } & \multirow{2}{*}{$\begin{array}{l}241=A A \\
241,190,51=A G \\
190,51=G G\end{array}$} \\
\hline & Reverse & ATGTTCTGGCATCTGGGAAG & & \\
\hline \multirow[t]{2}{*}{ rs1927911 } & Forward & TCACTTTGCTCAAGGGTCAA & \multirow[t]{2}{*}{ Styl } & \multirow{2}{*}{$\begin{array}{l}203=\pi \\
203,178,25=T C \\
178,25=C C\end{array}$} \\
\hline & Reverse & AAACCTGCATGCTCTGCAC & & \\
\hline \multirow[t]{2}{*}{ rs1927914 } & Forward & ACAAAATGGTCCCTCACAGC & \multirow[t]{2}{*}{ Sphl } & \multirow{2}{*}{$\begin{array}{l}150=\pi \\
157,90,67=T C \\
90,67=C C\end{array}$} \\
\hline & Reverse & TGGAAAGTAGCAAGTGCAATG & & \\
\hline
\end{tabular}


Table 2 rs 1927914 genotype genetic polymorphism distribution between cases and control

\begin{tabular}{|c|c|c|c|c|c|c|}
\hline \multirow{2}{*}{$\begin{array}{l}\text { Genotype } \\
\text { rs1927914 }\end{array}$} & \multirow{2}{*}{$\begin{array}{l}\text { Total } \\
\text { number } \\
n=133\end{array}$} & \multicolumn{2}{|c|}{ Studied groups } & \multirow[t]{2}{*}{$x^{2}$} & \multirow[t]{2}{*}{$p$ value } & \multirow[t]{2}{*}{ OR $(95 \% \mathrm{Cl})$} \\
\hline & & $\begin{array}{l}\text { Control } \\
n=50(\%)\end{array}$ & $\begin{array}{l}\text { Cases } \\
n=83(\%)\end{array}$ & & & \\
\hline $\mathrm{CC}$ & 63 & $8(12.7)$ & $55(87.3)$ & 39.9 & $<0.001^{*}$ & $15.3(6.05-38.6)$ \\
\hline $\mathrm{CT}$ & 12 & $2(16.7)$ & $10(83.3)$ & 11.3 & $0.007^{*}$ & $11.1(2.21-55.9)$ \\
\hline$\Pi(\mathrm{r})$ & 58 & $40(69.0)$ & $18(31.0)$ & & & 1 \\
\hline HW equilibrium & & $<0.001^{*}$ & $<0.001^{*}$ & & & \\
\hline
\end{tabular}

Significant association has been found as the homozygous CC genotype is more at risk for developing epilepsy than homozygous $\Pi \pi$ by 15.3 ( $p$ value $<0.001^{*}$ and OR 15.3). The heterozygous CT genotype is more at risk for developing epilepsy than $\Pi$ by 11.1 ( $p$ value $0.007^{*}$ and OR 11.1)

two divisions, according to response to the antiepileptic drug: group Ia with $40 \mathrm{AED}$ responders and a mean age of $6.83 \pm 4.57$ and group Ib with 43 drug resistance and a mean age of $8.58 \pm 4.14$.

Group II included 50 clinically healthy subjects from the same geographical area.

Our patients were diagnosed and classified according to the guidelines of the International League Against Epilepsy.

Exclusion criteria consisted of any significant medical disorders as hepatic disease or renal disease, brain cancer, history of pseudo-seizures, side effects of AEDs, and any progressive degenerative or metabolic brain disorders.

By the International League Against Epilepsy 2010, drug-resistant epilepsy was diagnosed as a nonresponse to AED after 2 or more adequate trials which properly chosen and tolerated either one drug or more.

The local ethical committee approved the study.

Information on epilepsy diagnosis, age of onset, duration, types of drugs, family history of epilepsy or other autoimmune diseases, and response to therapy were abstracted from medical reports.

\section{Genotyping}

The DNA was extracted from whole blood that was collected on EDTA tubes and reserved at $-20^{\circ} \mathrm{C}$, until use. The genomic extraction was done by using Thermo Scientific DNA Purification mini kit for whole blood. The genotyping was done for TLR4 rs11536858 (now merged into rs10759931), rs1927911, and rs1927914 by the polymerase chain reaction-restriction fragment length polymorphism (PCR-RFLP) method according to [2].

The sequences of both forward and reverse primers (purchased from Applied Biosystems) and restriction enzymes are described in Table 1 . The final reaction volume was $25 \mu \mathrm{l}$ which was composed of $4.0 \mu \mathrm{l} \mathrm{H} 2 \mathrm{O}$, $0.5 \mu \mathrm{l}$ from each primer (forward and reverse), $15.0 \mu \mathrm{l}$ DreamTaq Green PCR master mix (Tiagen, China), and $5 \mu \mathrm{l}$ DNA. The PCR reactions were done by using Thermocycler PTC-100 (Bio-Rad, USA). The first step was initial denaturation for $5 \mathrm{~min}$ at $95^{\circ} \mathrm{C}$, then 35 cycles for $40 \mathrm{~s}$ at $94{ }^{\circ} \mathrm{C}$, and $58^{\circ} \mathrm{C}$ for $45 \mathrm{~s}$ and $72{ }^{\circ} \mathrm{C}$ for $40 \mathrm{~s}$, and lastly the final extension step for $10 \mathrm{~min}$ at $72^{\circ} \mathrm{C}$. Before using restriction enzymes and to check PCR product, $5 \mu$ of the products mixed with $2 \mu \mathrm{l}$ of loading buffer were migrated on $2 \%$ agarose gel. For TLR4, rs11536858 was checked at $241 \mathrm{bp}, \mathrm{rs} 1927911$ at $203 \mathrm{bp}$, and rs1927914 at $157 \mathrm{bp}$.

The amplified PCR products for rs11536858, rs1927911, and rs1927914 were digested using the following restriction enzymes: KpnI, StyI, and SphI (New England Biolabs, USA) respectively. The total reaction volume was $30 \mu \mathrm{l}$ formed from $17 \mu \mathrm{l}$ nuclease-free water, $10 \mu \mathrm{l}$ of PCR products, $2.0 \mu \mathrm{l} 10 \mathrm{X}$ Fast Digest green buffer, and $1.0 \mu \mathrm{l}$ of restriction enzyme, and then the mixture was incubated. The temperature and duration of incubation was according to the manufacturer instructions. The DNA fragments produced from the reaction were revealed using agarose gel $3 \%$. The genotypes for each SNP are mentioned in Table 1.

\section{Statistical analysis}

The analysis of the data was done using IBM SPSS software package version 20.0. Quantitative data were described using mean and median range for nonparametric data, after testing normality using the Kolmogorov-Smirnov test. The significance of the obtained results was judged at $5 \%$ level.

The used tests were as follows: comparison of variables between studied groups by using the chi-square test and Kruskal-Wallis test for comparing non-parametric

Table 3 Association between rs1927914 alleles and epileptic cases

\begin{tabular}{|c|c|c|c|c|c|c|}
\hline \multirow{2}{*}{$\begin{array}{l}\text { Genotype } \\
\text { rs1927914 }\end{array}$} & \multirow{2}{*}{$\begin{array}{l}\text { Total } \\
\text { number } \\
n=266\end{array}$} & \multicolumn{2}{|c|}{ Studied groups } & \multirow[t]{2}{*}{$x^{2}$} & \multirow[t]{2}{*}{$p$ value } & \multirow[t]{2}{*}{ OR $(95 \% \mathrm{Cl})$} \\
\hline & & $\begin{array}{l}\text { Control } \\
n=100\end{array}$ & $\begin{array}{l}\text { Cases } \\
n=166\end{array}$ & & & \\
\hline $\bar{C}$ & 138 & $18(13.1)$ & $120(86.9)$ & 73.7 & $<0.001^{*}$ & 1 \\
\hline$T(r)$ & 128 & $82(64.1)$ & $46(35.9)$ & & & $11.9(6.4-21.9)$ \\
\hline
\end{tabular}

The total number of cases is 266; as it is the number of alleles, we duplicated the number of cases to be 266 instead of 133 ; a significant association between cases and control has been found as $C$ allele is more at risk for developing epilepsy than $T$ allele 
Table 4 Association between TLR genetic polymorphism rs1927914 and epilepsy type

\begin{tabular}{|c|c|c|c|c|c|c|}
\hline \multirow{2}{*}{$\begin{array}{l}\text { Genotype } \\
\text { rs1927914 }\end{array}$} & \multirow{2}{*}{$\begin{array}{l}\text { Total } \\
\text { cases } \\
n= \\
83\end{array}$} & \multicolumn{2}{|c|}{ Epilepsy type } & \multirow[t]{2}{*}{$x^{2}$} & \multirow[t]{2}{*}{$p$} & \multirow[t]{2}{*}{ OR $(95 \% \mathrm{Cl})$} \\
\hline & & $\begin{array}{l}\text { Primary } \\
n=61(\%)\end{array}$ & $\begin{array}{l}\text { Secondary } \\
n=22(\%)\end{array}$ & & & \\
\hline$\overline{C C}$ & 55 & $39(70.9)$ & $16(29.1)$ & 10.5 & $0.001^{*}$ & $6.3(1.9-20.7)$ \\
\hline$C T$ & 10 & $9(90.0)$ & $1(10.0)$ & 1.21 & 0.27 & $0.29(0.03-2.9)$ \\
\hline$\Pi \pi(r)$ & 18 & $13(72.2)$ & $5(27.8)$ & & & 1 \\
\hline \multicolumn{2}{|c|}{ HW equilibrium } & $<0.001^{*}$ & $<0.001^{*}$ & & & \\
\hline
\end{tabular}

Significant association was detected as $p$ value $0.001^{*}$; cases with CC genotype are more at risk for developing primary epilepsy than TT cases by 6.3 times (OR $=6.3$ )

continuous variables of more than 2 studied groups. Mann-Whitney $U$ test was used for comparing nonparametric continuous variables between the 2 studied groups. Hardy-Weinberg equilibrium was used to compare the frequency of genotype deviation from the general population. The odd ratio was calculated using cross tabulation through Epi Info. In allele statistics, we did the duplication for the studied groups for calculation of each allele frequency (number of cases $=166$ and control $=100$ ), and in allele combination or haplotype combination, we did the combination between the studied alleles (cases $=332$ and control $=200$ ).

\section{Results}

According to $r s 1927914$ genotypes in Table 2, the homozygous CC genotypes are 15.3 times ( $p$ value $<0.001^{*}$ and OR 15.3) more at risk for developing epilepsy than homozygous TT. The heterozygous CT genotype is 11.1 times ( $p$ value $0.007^{*}$ and OR 11.1) more at risk for developing epilepsy than TT. Also, $\mathrm{C}$ alleles are 11.9 times ( $p$ value $<0.001^{*}$ and OR 11.9) more at risk for developing epilepsy than the $\mathrm{T}$ allele, as shown in Table 3.

The association between TLR genetic polymorphism rs1927914 and epilepsy types were presented in Table 4; a significant association was detected as $p$ value was $0.001^{*}$, cases with CC genotype are more risky for developing primary epilepsy than TT cases by 6.3 times (OR = 6.3). Hardy-Weinberg equilibrium illustrates a statistically significant deviation of $r s 1927914$ genotype among primary and secondary epilepsy cases. However, the rs1927914 allele demonstrates a non-statistically significant association with epilepsy types (primary and secondary), as mentioned in Table 5.
A significant association was found in homozygoze AA genotypes of rs11536858, being more risky for developing epilepsy than homozygoze GG by 14.5 times with $p$ value $<0.001^{*}$ and OR 14.5. A allele is 3.8 times more at risk for developing epilepsy than $\mathrm{G}$ allele with $p$ value < $0.001 \%$ and OR 3.8, as mentioned in Tables 6 and 7 , respectively.

Analysis of the association between drug resistance and genotypes was analyzed in Table 8 . It had a statistically significant association between clonazepam resistance and rs11536858 as a $p$ value $<0.001$ * with the highest frequency with AA genotypes (4.3\%).

According to rs1927911, no significant results were found between study cases and control groups, or between drug-responsive and drug resistance, as shown in Tables 9 and 10.

According to the rs 11536858 and $r s 1927914$ allele combination, there is a statistically significant difference between the study cases and control groups regarding all combinations. The highest combination frequency among cases was CG (82.2\%), and then CA (36.8\%), as shown in Table 11.

The highest frequency of genotype combination among case was CC/TT/CT (22.9\%) followed by CC/ $\mathrm{CT} / \mathrm{CT}$ (15.7\%) while the among control group, TT/CT/ CT (32\%) was the highest followed by $\mathrm{TT} / \mathrm{CC} / \mathrm{CT}$ (16.0\%). Genotype combinations have a statistically significant difference between study cases and control groups which were CC/TT/CT, TT/CC/CT, TT/CT/CC, and TT/CT/CT, as shown in Table 12.

\section{Discussion}

Epilepsy is one of the most common neurological disorders. It represents about $27 \%$ of all neurological diagnosis. Different studies from Egypt reported the prevalence of epilepsy

Table 5 Association between TLR genetic polymorphism rs 1927914 alleles and epilepsy type

\begin{tabular}{|c|c|c|c|c|c|c|}
\hline \multirow{2}{*}{$\begin{array}{l}\text { Genotype } \\
\text { rs1927914 }\end{array}$} & \multirow{2}{*}{$\begin{array}{l}\text { Total } \\
\text { number } \\
n=166\end{array}$} & \multicolumn{2}{|c|}{ Studied groups } & \multirow[t]{2}{*}{$x^{2}$} & \multirow{2}{*}{$\begin{array}{l}p \\
\text { value }\end{array}$} & \multirow[t]{2}{*}{ OR $(95 \% \mathrm{Cl})$} \\
\hline & & $\begin{array}{l}\text { Primary } \\
n=122(\%)\end{array}$ & $\begin{array}{l}\text { Secondary } \\
n=44(\%)\end{array}$ & & & \\
\hline $\mathrm{C}$ & 120 & 87 (71.3) & $33(75.0)$ & 0.22 & 0.64 & $1.21(0.55-2.65)$ \\
\hline$T(r)$ & 46 & 35 (38.7) & $11(25.0)$ & & & 1 \\
\hline
\end{tabular}

No significant association has been found 
Table 6 rs11536858 Genotype distribution between cases and control

\begin{tabular}{|c|c|c|c|c|c|c|}
\hline \multirow{2}{*}{$\begin{array}{l}\text { Genotype } \\
\text { rs11536858 }\end{array}$} & \multirow{2}{*}{$\begin{array}{l}\text { Total } \\
\text { number } \\
n=133\end{array}$} & \multicolumn{2}{|c|}{ Studied groups } & \multirow[t]{2}{*}{$x^{2}$} & \multirow[t]{2}{*}{$p$ value } & \multirow[t]{2}{*}{ OR $(95 \% \mathrm{Cl})$} \\
\hline & & $\begin{array}{l}\text { Control } \\
n=50(\%)\end{array}$ & $\begin{array}{l}\text { Cases } \\
n=83(\%)\end{array}$ & & & \\
\hline$\overline{G G(r)}$ & 19 & $13(68.4)$ & $6(31.6)$ & & & 1 \\
\hline GA & 60 & $30(50.0)$ & $30(50.0)$ & 1.97 & 0.16 & $2.2(0.73-6.5)$ \\
\hline $\mathrm{AA}$ & 54 & $7(13.0)$ & 47 (87.0) & 21.7 & $<0.001^{*}$ & $14.5(4.2-50.8)$ \\
\hline HW equilibrium & & 0.88 & 0.69 & & & \\
\hline
\end{tabular}

Significant association has been found. Homozygoze AA genotype is more at risk for developing epilepsy than homozygoze GG by 14.5 with $p$ value < $0.001^{*}$ and OR 14.5)

among Egyptian children. A study reported that the lifetime prevalence of epilepsy in children below 18 years old was 9.7/1000 [6]. Another two studies reported a prevalence of 7-10/1000 among children at school who were less than 15 years of age $[7,8]$, while another study reported a higher rate of 12.9/1000 among children < 12 years [9].

Multiple findings encourage us to study the TLR4 in epilepsy. Firstly, TLR4 expression in the brain tissue was proven in different studies [10-12]. Secondly, growing evidence supports the hypothesis that inflammation within brain tissue is a cornerstone for the development of seizures [13-17]. Thirdly, the relation between TLR4, as a key player in innate immune response, and epilepsy has been found on both molecular and pharmacological levels [18-20]. Previous researches were lacking proper studies on children, so we decided to do our pediatric study.

In the present study on a cohort of Egyptian pediatric patients, we tried to strengthen the previous findings concerning the relation between TLR4 and epilepsy by investigating this relation on the genetic level. We focused on 3 SNPs in TLR4 (rs1927911, rs1927914, and rs11536858). These SNPs have been studied in different disorders with or without immunological bases like prostate cancer [21], Alzheimer [22], normal-tension glaucoma [23], and kidney transplant rejection [24]. To our knowledge, this is the first study investigating TLR4 gene polymorphisms and their relation to epilepsy development and antiepileptic drug resistance.

Our results showed a significant association between homozygous CC and heterozygous CT genotypes of TLR4 rs1927914, homozygous AA genotype of TLR4 rs11536858, and epilepsy $(p<0.05)$. These genotypes can be considered as a risk factor for epilepsy

Table 7 rs11536858 allele distribution between cases and control

\begin{tabular}{|c|c|c|c|c|c|}
\hline \multirow{2}{*}{$\begin{array}{l}\text { rs11536858 } \\
\text { allele }\end{array}$} & \multicolumn{2}{|c|}{ Studied groups } & \multirow[t]{2}{*}{$x^{2}$} & \multirow[t]{2}{*}{$p$ value } & \multirow{2}{*}{$\begin{array}{l}\text { OR }(95 \% \\
\text { Cl) }\end{array}$} \\
\hline & $\begin{array}{l}\text { Control } \\
n=100\end{array}$ & $\begin{array}{l}\text { Cases } \\
n=166\end{array}$ & & & \\
\hline$G(r)$ & $56(57.1)$ & $42(42.9)$ & 25.3 & $<0.001^{*}$ & 1 \\
\hline A & $44(26.2)$ & $124(73.8)$ & & & $3.8(2.2-6.4)$ \\
\hline
\end{tabular}

Significant association has been found as $A$ allele is more at risk for developing epilepsy than $\mathrm{G}$ allele by 3.8 with $p$ value $<0.001^{*}$ and OR 3.8 ) development. Also, the C allele for rs1927914 can be considered a risky allele $(p<0.001)$; on the other hand, the $\mathrm{G}$ allele for rs11536858 can be considered as a protective allele $(p<0.001)$. For epilepsy subtypes, either primary or secondary, a significant association was found between CC genotype of rs1927914 and primary epilepsy $(p<0.001)$. There was no significant association between rs1927911 (genotype and alleles) and epilepsy ( $p>0.05)$.

In literature, different studies supported the role of TLR4 in one of the following: occurrence, severity, and/ or persistence of epilepsy. TLR4 astrocyte mediates the development of the excitatory synapse in young mice after strong immune activation, and this effect could be blocked by TLR4 antagonists [25]. The same findings were recorded by an earlier study after intraperitoneal injections of LPS in 2-week-old mice [26]. High mobility group box 1 (HMGB1), the ligand for TLR4, together with TLR4, was found to have more expression in drugresistant temporal lope epilepsy; moreover, they found an increase in the frequency of seizures in the mice model with increased expression of HMGB1 [3]. The same result was obtained when HMGB1 serum level was measured in epilepsy cases [27]. In the same context, a

Table 8 Association between rs11536858 genotype and epilepsy drugs used

\begin{tabular}{|c|c|c|c|c|c|}
\hline \multirow[t]{2}{*}{ Drug } & \multicolumn{3}{|c|}{ rs11536858 genotype } & \multirow[t]{2}{*}{$x^{2}$} & \multirow[t]{2}{*}{$p$} \\
\hline & $\begin{array}{l}\text { GG } \\
n=6(\%)\end{array}$ & $\begin{array}{l}\mathrm{GA} \\
n=30(\%)\end{array}$ & $\begin{array}{l}\text { AA } \\
n=47(\%)\end{array}$ & & \\
\hline Na valproate & $6(100)$ & $29(96.7)$ & $39(83.0)$ & 4.3 & 0.11 \\
\hline Carbamazepine & $1(16.7)$ & $4(13.3)$ & $14(29.8)$ & 2.9 & 0.23 \\
\hline Levitracetapine & $5(83.3)$ & $17(56.7)$ & $24(51.1)$ & 2.3 & 0.32 \\
\hline Oxacarbamazepine & 0 & $4(13.3)$ & $6(1.8)$ & 0.9 & 0.64 \\
\hline Topiramate & $3(50.0)$ & $10(33.3)$ & $12(25.5)$ & 1.7 & 0.42 \\
\hline Clonazepam & $4(66.7)$ & $1(3.3)$ & $2(4.3)$ & 28.4 & $<0.001^{*}$ \\
\hline Phenytoin & 0 & $2(6.7)$ & $1(2.1)$ & 1.3 & 0.52 \\
\hline Lacosamide & 0 & 0 & $1(2.1)$ & 0.78 & 0.68 \\
\hline Lamotrigine & 0 & $1(3.3)$ & $3(6.4)$ & 0.69 & 0.71 \\
\hline
\end{tabular}

Statistically significant association between clonazepam resistance and rs11536858 as $p$ value $<0.001$ * with the highest frequency with AA genotypes (4.3) \% 
Table 9 rs1927911 genetic polymorphism distribution between cases and control

\begin{tabular}{|c|c|c|c|c|c|}
\hline \multirow{2}{*}{$\begin{array}{l}\text { Genotype } \\
\text { rs1927911 }\end{array}$} & \multicolumn{2}{|c|}{ Studied groups } & \multirow[t]{2}{*}{$x^{2}$} & \multirow{2}{*}{$\begin{array}{l}p \\
\text { value }\end{array}$} & \multirow[t]{2}{*}{ OR $(95 \% \mathrm{Cl})$} \\
\hline & $\begin{array}{l}\text { Control } \\
n=50\end{array}$ & $\begin{array}{l}\text { Cases } \\
n=83\end{array}$ & & & \\
\hline$\overline{C C}$ & $13(31.0)$ & $29(69)$ & 1.5 & 0.22 & $2.2(0.6-8.2)$ \\
\hline CT & 31 (39.2) & $48(60.8)$ & 0.49 & 0.37 & $1.55(0.46-5.2$ \\
\hline$\Pi(\mathrm{r})$ & $6(50.0)$ & $6(50.0)$ & & & 1 \\
\hline
\end{tabular}

No significant results were found between cases and control

higher dose of kinic acid was needed to induce epileptic fits in TLR4 knockout mice [28]. Another study found that increased TLR4 expression was associated with an increase in the frequency of fits [29].

Regarding AEDs resistance, patients with multiple AEDs usually develop drug resistance. We examined the relation between TLR4 SNPs and resistance to different AEDs like $\mathrm{Na}$ valproate, carbamazepine, clonazepam, phenytoin, and topiramate. No relation was found between the studied SNPs and drug resistance except for the rs11536858 with clonazepam $(p<0.001)$. This association may be explained by the association of this genotype with benzodiazepine receptor action in epilepsy. The relation between gene polymorphisms and AEDs resistance was investigated in different studies. In previous studies, for example, they focused on ABCB1 C343T polymorphism with different findings [30-32].

Stimulation of TLR4 either by exogenous agent (LPS) or endogenous ligand (heat shock protein) enhances the production of pro-inflammatory mediators like IL1, TNF, prostaglandins, and complement cascade, which has an active role in seizures development and exacerbation [33-35]. Myeloid differentiation 88 (MYD88) is an essential intracellular mediator for TLR4 signaling; after TLR4 stimulation by LPS in young animals, the formation of excitatory synapses is increased by the activation of TLR4-MyD88-ERK (excitatory signal regulated kinase) signaling pathway [26]. Another theory explains that the role of TLR4 in epilepsy involves HMGB1. Activation of the TLR4-HMGB1 pathway enhances the release of $\mathrm{Ca}$, which increases the excitability of neurons, as well as neuronal damage, and decreases the threshold for fit development, which means more frequency of epileptic fits [36, 37]. In a pilocarpine rat model of epilepsy, early

Table 10 rs 1927911 allele polymorphism distribution between cases and control

\begin{tabular}{|c|c|c|c|c|c|c|}
\hline \multirow{2}{*}{$\begin{array}{l}\text { Allele } \\
\text { rs1927911 }\end{array}$} & \multirow{2}{*}{$\begin{array}{l}\text { Total } \\
\text { number } \\
n=266\end{array}$} & \multicolumn{2}{|c|}{ Studied groups } & \multirow[t]{2}{*}{$x^{2}$} & \multirow{2}{*}{$\begin{array}{l}p \\
\text { value }\end{array}$} & \multirow{2}{*}{$\begin{array}{l}\text { OR } \\
(95 \% \mathrm{Cl})\end{array}$} \\
\hline & & $\begin{array}{l}\text { Control } \\
n=100\end{array}$ & $\begin{array}{l}\text { Cases } \\
n=166\end{array}$ & & & \\
\hline$C(r)$ & 163 & 57 (34.9) & $106(65.03)$ & 1.24 & 0.27 & 1 \\
\hline $\mathrm{T}$ & 103 & $43(41.7)$ & $60(58.3)$ & & & $1.33(0.8-2.2)$ \\
\hline
\end{tabular}

No significant results were found between cases and control (the total number of cases is 266; as it is the number of alleles, we duplicated the number of cases to be 266 instead of 133)
Table 11 rs11536858 and rs 1927914 allele combination distribution between cases and control

\begin{tabular}{lllll}
\hline $\begin{array}{l}\text { Haplotype } \\
\text { combination }\end{array}$ & $\begin{array}{l}\text { Control } \\
\boldsymbol{N}=\mathbf{4 0 0}(\%)\end{array}$ & $\begin{array}{l}\text { Cases } \\
\boldsymbol{N}=\mathbf{6 6 4}(\%)\end{array}$ & $\begin{array}{l}\text { Test of } \\
\text { significance }\end{array}$ & $\begin{array}{l}\text { Bonferroni } \\
\text { correction }\end{array}$ \\
\hline CG & $74(18.5)$ & $162(82.2)$ & $p=0.02^{*}$ & $p=0.01^{*}$ \\
CA & $62(15.5)$ & $244(36.8)$ & $p<0.001^{*}$ & $p=0.001^{*}$ \\
TG & $138(34.5)$ & $88(13.3)$ & $p<0.001^{*}$ & $p=0.001^{*}$ \\
TA & $126(31.5)$ & $170(25.6)$ & $p=0.03^{*}$ & $p=0.015^{*}$ \\
\hline
\end{tabular}

There is a statistically significant difference between cases and control regarding all combinations with the highest combination frequency among cases being CG $(82.2 \%)$ and then CA $(36.8 \%)$

activation of TLR4 and TLR2, probably through preserving normal hippocampal cytokine profile and neuronal function, attenuates seizure severity [38]. A new therapeutic approach of epilepsy by using TLR7 inhibitors has been suggested after observing the neuroinflammatory cascade using the microRNAs TLR7 activator [39]. Accordingly, Liao et al. suggested that electronic

Table 12 Genotype combination among studied cases and control groups

\begin{tabular}{|c|c|c|c|}
\hline Genotype combination & $\begin{array}{l}\text { Control } \\
n=50\end{array}$ & $\begin{array}{l}\text { Cases } \\
n=83\end{array}$ & \\
\hline $\mathrm{CC} / \mathrm{CC} / \mathrm{CC}$ & $1(2.0)$ & $0(0.0)$ & FET, $p=0.38$ \\
\hline $\mathrm{CC} / \mathrm{CC} / \mathrm{CT}$ & $1(2.0)$ & $3(3.6)$ & FET, $p=1.0$ \\
\hline $\mathrm{CC} / \mathrm{CT} / \mathrm{CC}$ & $1(2.0)$ & $7(8.4)$ & $x^{2}=2.26, p=0.13$ \\
\hline $\mathrm{CC} / \mathrm{CT} / \mathrm{CT}$ & $3(6.0)$ & $13(15.7)$ & $x^{2}=2.75, p=0.09$ \\
\hline $\mathrm{CC} / \mathrm{CT} / \mathrm{TT}$ & $1(2.0)$ & $0(0.0)$ & FET, $p=0.38$ \\
\hline $\mathrm{CC} / \mathrm{TT} / \mathrm{CC}$ & $1(2.0)$ & $9(10.8)$ & $x^{2}=3.5, p=0.06$ \\
\hline $\mathrm{CC} / \mathrm{TT} / \mathrm{CT}$ & $0(0.0)$ & $19(22.9)$ & $x^{2}=13.4, p=0.002^{*}$ \\
\hline $\mathrm{CC} / \mathrm{TT} / \mathrm{TT}$ & $1(2.0)$ & $4(4.8)$ & FET, $p=0.65$ \\
\hline $\mathrm{CT} / \mathrm{CC} / \mathrm{TT}$ & $1(2.0)$ & $0(0.0)$ & FET, $p=0.38$ \\
\hline $\mathrm{CT} / \mathrm{CT} / \mathrm{CC}$ & $1(2.0)$ & $2(2.4)$ & FET, $p=1.0$ \\
\hline $\mathrm{CT} / \mathrm{CT} / \mathrm{TT}$ & $0(0.0)$ & $1(1.2)$ & FET, $p=1.0$ \\
\hline $\mathrm{CT} / \mathrm{TT} / \mathrm{CC}$ & $0(0.0)$ & $4(4.8)$ & FET, $p=0.29$ \\
\hline $\mathrm{CT} / \mathrm{TT} / \mathrm{CT}$ & $0(0.0)$ & $2(2.4)$ & FET, $p=0.53$ \\
\hline $\mathrm{CT} / \mathrm{TT} / \mathrm{TT}$ & $0(0.0)$ & $1(1.2)$ & $\mathrm{FET}, p=1.0$ \\
\hline TT/CC/CC & $0(0.0)$ & $3(3.6)$ & FET, $p=0.29$ \\
\hline$\Pi \mathrm{T} / \mathrm{CC} / \mathrm{CT}$ & $8(16)$ & $0(0.0)$ & $x^{2}=14.12, p=0.002^{*}$ \\
\hline$\Pi \mathrm{T} / \mathrm{CC} / \mathrm{TT}$ & $2(4)$ & $0(0.0)$ & FET, $p=0.14$ \\
\hline$\Pi$ T/CT/CC & $7(14)$ & $2(2.4)$ & $x^{2}=6.64, p=0.009^{*}$ \\
\hline TT/CT/CT & $16(32)$ & $5(6.0)$ & $x^{2}=15.83, p=0.001^{*}$ \\
\hline$\Pi \mathrm{T} / \mathrm{CT} / \mathrm{TT}$ & $1(2)$ & $0(0.0)$ & FET, $p=0.38$ \\
\hline ТT/TT/CC & $2(4)$ & $2(2.4)$ & FET, $p=0.63$ \\
\hline TT/TT/CT & $3(6)$ & $6(7.2)$ & $x^{2}=0.07, p=0.78$ \\
\hline Total & $50(100.0)$ & $83(100.0)$ & \\
\hline
\end{tabular}

The highest frequency of genotype combination among cases was CC/TT/CT (22.9\%) followed by CC/CT/CT (15.7\%) while among the control group, TT/CT/ CT (32\%) was the highest followed by TT/CC/CT (16.0\%). Genotype combinations have a statistically significant difference between cases and control groups which were $\mathrm{CC} / \mathrm{TT} / \mathrm{CT}, \mathrm{TT} / \mathrm{CC} / \mathrm{CT}$, TT/CT/CC, and TT/CT/CT 
stimulation of the ear could control epileptic seizures by TLR4 signaling pathway regulation, which may be a novel therapeutic approach for epileptic seizures [40].

\section{Conclusion}

Possible involvement of the Toll-like receptor clarifies the importance of innate immunity in initiating seizures and making neuronal hyperexcitability. In this work, multiple significant associations between TLR SNPs and epilepsy, epileptic phenotype, and drug-resistant epilepsy have been found. More studies with larger samples sizes and different techniques along with different SNPs are recommended to find potential immunotherapeutic approaches as a sole or adjuvant therapy for epilepsy.

\section{Abbreviations}

AEDs: Antiepileptic drugs; DAMPs: Damage-associated molecular patterns; HMGB1: High mobility group box 1 protein; LPS: Lipopolysaccharide; MAF: Minor allele frequencies; PCR: Polymerase chain reaction-restriction fragment length; RFLP: Restriction fragment length polymorphism; SNP: Single-nucleotide polymorphisms; TLR4: Toll-like receptor 4

\section{Acknowledgements}

We would like to acknowledge DR/Amira Ragheb, CT, ASCP, for her great effort in providing language editing.

\section{Authors' contributions}

MA wrote the paper and analyzed and interpreted the patient data regarding the disease. DS performed the examination of the patient and collection of the samples. HM made the statistical analysis of the data. AM participated in the writing. MM was a major contributor in writing the manuscript. All authors read and approved the final manuscript.

\section{Funding}

No available funding

\section{Availability of data and materials}

The data that support the findings of this study are available from the corresponding author upon reasonable request.

\section{Ethics approval and consent to participate}

This study was approved by the ethics committee of Faculty of Medicine, Mansoura University, with approval number [R.20.04.808]. The patient provided written consent.

\section{Consent for publication}

Written parental consent had been taken, and this was approved by the ethics committee.

\section{Competing interests}

The authors declare that they have no competing interests.

\section{Author details}

${ }^{1}$ Immunology Unit, Clinical Pathology Department, Faculty of Medicine, Mansura University, Mansoura, Egypt. ${ }^{2}$ Immunology Department, Egypt Center for Research and Regenerative Medicine (ECRRM), Cairo 11517, Egypt. ${ }^{3}$ Department of Pediatrics, Faculty of Medicine, Mansoura University, Mansoura, Egypt. ${ }^{4}$ Public Health \& Community Medicine Department, Faculty of medicine, Mansura University, Mansoura, Egypt. ${ }^{5}$ Medical Microbiology and Immunology Department, Faculty of Medicine, Mansura University, Mansoura, Egypt.
Received: 11 June 2020 Accepted: 16 October 2020

Published online: 18 December 2020

\section{References}

1. Vezzani A, French J, Bartfai T, Baram TZ (2011) The role of inflammation in epilepsy. Nat Rev Neurol 7:31-40

2. Singh K, Singh VK, Agrawal NK, Gupta KS, Singh K (2013) Association of Tolllike receptor 4 polymorphisms with diabetic foot ulcers and application of artificial neural network in DFU risk assessment in type 2 diabetes patients. Biomed Res Int:318686. https://doi.org/10.1155/2013/318686

3. Maroso M, Balosso S, Ravizza T, Liu J, Aronica E, lyer AM et al (2010) Toll-like receptor 4 and high-mobility group box-1 are involved in ictogenesis and can be targeted to reduce seizures. Nat Med 16:413-419

4. Suleiman J, Wright S, Gill D, Brilot F, Waters P, Peacock K et al (2013) Autoantibodies to neuronal antigens in children with new-onset seizures classified according to the revised ILAE organization of seizures and epilepsies. Epilepsia 15:2091-2100

5. Beghi E (2010) Treating epilepsy across its different stages. Ther Adv Neurol Disord 3:85-92

6. Farghaly WM, Abd Elhamed MA, Hassan EM, Soliman WT, Yhia MA, Hamdy NA (2018) Prevalence of childhood and adolescence epilepsy in upper Egypt (desert areas). Egypt J Neurol Psychiatr Neurosurg 54(1):34

7. El-Motayam AJEZU. Epidemiological study of neurological diseases in young age. 1992.

8. El-Tallawy HN, Farghaly WM, Rageh TA, Shehata GA, Metwally NA, Badry R et al (2016) Spectrum of epilepsy - prevalence, impact, and treatment gap: an epidemiological study from Al-Quseir, Egypt. Neuropsychiatr Dis Treat 12: $1111-1118$

9. Shawki AJMTiNFoM, Assiut University. Etiological and clinical presentation of epilepsy in Upper Egypt. 1995.

10. Alfonso-Loeches S, Pascual-Lucas M, Blanco AM, Sanchez-Vera I, Guerri CJJoN. Pivotal role of TLR4 receptors in alcohol-induced neuroinflammation and brain damage. 2010;30(24):8285-95

11. Chen Z, Jalabi W, Shpargel KB, Farabaugh KT, Dutta R, Yin X, et al. Lipopolysaccharide-induced microglial activation and neuroprotection against experimental brain injury is independent of hematogenous TLR4. 2012;32(34):11706-15.

12. Jou I, Lee JH, Park SY, Yoon HJ, Joe E-H, Park EJ. Gangliosides trigger inflammatory responses via TLR4 in brain glia. 2006;168(5):1619-30.

13. Choi J, Nordli DR, Alden TD, DiPatri A, Laux L, Kelley K, et al. Cellular injury and neuroinflammation in children with chronic intractable epilepsy. 2009; 6(1):38.

14. Riazi K, Galic MA, Pittman QJ. Contributions of peripheral inflammation to seizure susceptibility: cytokines and brain excitability. 2010;89(1):34-42.

15. Vezzani A, Baram TZ. New roles for interleukin-1 Beta in the mechanisms of epilepsy. 2007;7(2):45-50

16. Vezzani A, Friedman A (2011) Brain inflammation as a biomarker in epilepsy. Biomark Med 5(5):607-614

17. Vezzani A, Granata TJE. Brain inflammation in epilepsy: experimental and clinical evidence. 2005:46(11):1724-43.

18. Chen G, Zhang S, Shi J, Ai J, Qi M, Hang C. Simvastatin reduces secondary brain injury caused by cortical contusion in rats: possible involvement of TLR4/NF-kB pathway. 2009;216(2):398-406

19. Wang $L$, Zhang $X$, Liu L, Yang R, Cui L, Li M. Atorvastatin protects rat brains against permanent focal ischemia and downregulates HMGB1, HMGB1 receptors (RAGE and TLR4), NF-KB expression. 2010;471(3):152-6.

20. Zhu H-T, Bian C, Yuan J-C, Chu W-H, Xiang X, Chen F, et al. Curcumin attenuates acute inflammatory injury by inhibiting the TLR4/MyD88/NFKB signaling pathway in experimental traumatic brain injury. 2014;11(1): 59.

21. Song J, Kim DY, Kim CS, Kim HJ, Lee DH, Lee Hyun M et al (2009) The association between toll-like receptor 4 (TLR4) polymorphisms and the risk of prostate cancer in Korean men. Cancer Genet Cytogenetics 190(2):88-92

22. Jin-Tai Y, Dan M, Wei-Zhen C, Jiang-Rong O, Yan T, Zhong-Chen W et al (2012) Common variants in toll-like receptor 4 confer susceptibility to Alzheimer's disease in a Han Chinese population. Current Alzheimer Res 9(4):458-466

23. Shibuya E, Meguro A, Ota M, Kashiwagi K, Mabuchi F, lijima H et al (2008) Association of toll-like receptor 4 gene polymorphisms with normal tension glaucoma. Invest Ophthalmol Vis Sci 49(10):4453-4457 
24. Hwang Y-H, Ro H, Choi I, Kim H, Oh K-H, Hwang J-I, et al. Impact of polymorphisms of TLR4/CD14 and TLR3 on acute rejection in kidney transplantation. 2009;88(5):699-705.

25. Sobieski C, Christian CA. Developmental inflammation takes a toll: early immune responses increase seizure susceptibility via astrocytic TLR4 signaling. 2017;17(6):370-1.

26. Shen $Y$, Qin H, Chen J, Mou L, He Y, Yan Y et al (2016) Postnatal activation of TLR4 in astrocytes promotes excitatory synaptogenesis in hippocampal neurons. J Cell Biol 215(5):719-734

27. Kan M, Song L, Zhang $X$, Zhang J, Fang P. Circulating high mobility group box-1 and toll-like receptor 4 expressions increase the risk and severity of epilepsy. Braz J Med Biol Res. 2019;52(7):e7374-e.

28. Iori V, Maroso M, Rizzi M, lyer AM, Vertemara R, Carli M, et al. Receptor for advanced glycation endproducts is upregulated in temporal lobe epilepsy and contributes to experimental seizures. 2013:58:102-14.

29. Pernhorst K, Herms S, Hoffmann P, Cichon S, Schulz H, Sander T, et al. TLR4, ATF-3 and IL8 inflammation mediator expression correlates with seizure frequency in human epileptic brain tissue. 2013;22(8):675-8.

30. Hung C-C, Tai JJ, Lin C-J, Lee M-J, Liou H-H (2005) Complex haplotypic effects of the $A B C B 1$ gene on epilepsy treatment response. Pharmacogenomics. 6(4):411-417

31. Shaheen U, Prasad DKV, Sharma V, Suryaprabha T, Ahuja YR, Jyothy A et al (2014) Significance of MDR1 gene polymorphism C3435T in predicting drug response in epilepsy. Epilepsy Res 108(2):251-256

32. Stasiołek M, Romanowicz H, Połatyńska K, Chamielec M, Skalski D, Makowska $\mathrm{M}$, et al. Association between C3435T polymorphism of MDR1 gene and the incidence of drug-resistant epilepsy in the population of Polish children. Behav Brain Funct. 2016;12(1):21 -

33. Okun E, Griffioen KJ, Mattson MP (2011) Toll-like receptor signaling in neural plasticity and disease. Trends Neurosci 34(5):269-281

34. Xiong Z-Q, Qian W, Suzuki K, McNamara JO (2003) Formation of complement membrane attack complex in mammalian cerebral cortex evokes seizures and neurodegeneration. J Neurosci 23(3):955-960

35. Yao L, Kan EM, Lu J, Hao A, Dheen ST, Kaur C, et al. Toll-like receptor 4 mediates microglial activation and production of inflammatory mediators in neonatal rat brain following hypoxia: role of TLR4 in hypoxic microglia. J Neuroinflammation. 2013:10:23.

36. Gardella S, Andrei C, Ferrera D, Lotti LV, Torrisi MR, Bianchi ME et al (2002) The nuclear protein HMGB1 is secreted by monocytes via a non-classical, vesicle-mediated secretory pathway. EMBO Rep 3(10):995-1001

37. Walker LE, Frigerio F, Ravizza T, Ricci E, Tse K, Jenkins RE et al (2017) Molecular isoforms of high-mobility group box 1 are mechanistic biomarkers for epilepsy. J Clin Invest 127(6):2118-2132

38. Mahshid H., Hamid G., Fariba K., Mahtab D., Nima N., Fereshteh M. Preconditioning with toll-like receptor agonists attenuates seizure activity and neuronal hyperexcitability in the pilocarpine rat model of epilepsy 2019.1:408:388-399

39. Alan A. D., Daniela C, Shruti B, McKenzie J, Joseph A. C, Harry T. C \& Diane C. TLR7 activation in epilepsy of tuberous sclerosis complex. Inflammation Research (2019) 68, 993-998.

40. En-Tzu L., Yi-Wen L., Chun-Pi., Nou-Y., and Ching-L. Electric stimulation of ear reduces the effect of toll-like receptor 4 signaling pathway on kainic acidinduced epileptic seizures in rats. 2018 |Article ID 5407256 | 11 pages | https://doi.org/10.1155/2018/5407256

\section{Publisher's Note}

Springer Nature remains neutral with regard to jurisdictional claims in published maps and institutional affiliations.

\section{Submit your manuscript to a SpringerOpen ${ }^{\circ}$ journal and benefit from:}

- Convenient online submission

- Rigorous peer review

- Open access: articles freely available online

- High visibility within the field

- Retaining the copyright to your article

Submit your next manuscript at $\boldsymbol{\nabla}$ springeropen.com 